\title{
Applesnails (of Florida), Pomacea spp. (Gastropoda: Prosobranchia: Pilidae) $)^{1}$
}

Lionel A. Stange ${ }^{2}$

\section{Introduction}

The applesnails belong to the subclass Prosobranchia of the Gastropoda which are distinguished from the other subclass, Pulmonata, by the presence of an operculum. The operculum is a cover used to close the aperture when the snails are withdrawn into their shells. Applesnails are larger than most freshwater snails and can be separated from other freshwater species by their oval shell which has the umbilicus of the shell perforated or broadly open. The spire of the shell can be conspicuous but is much less than the height of the aperture. The operculum (which detaches after death) is corneous with concentric growth rings. Applesnails lay grape-like clusters of pink to red eggs on solid objects above the water which provides the fastest way to determine if applesnails are present.

There are three species in Florida. One is native and the others are introduced. The Florida applesnail, Pomacea paludosa, occurs throughout peninsular Florida (Thompson 1984). It is the principal food of the Everglades Kite (Rostrhamus sociabilis plumbeus Ridgway) and thus should be considered beneficial.

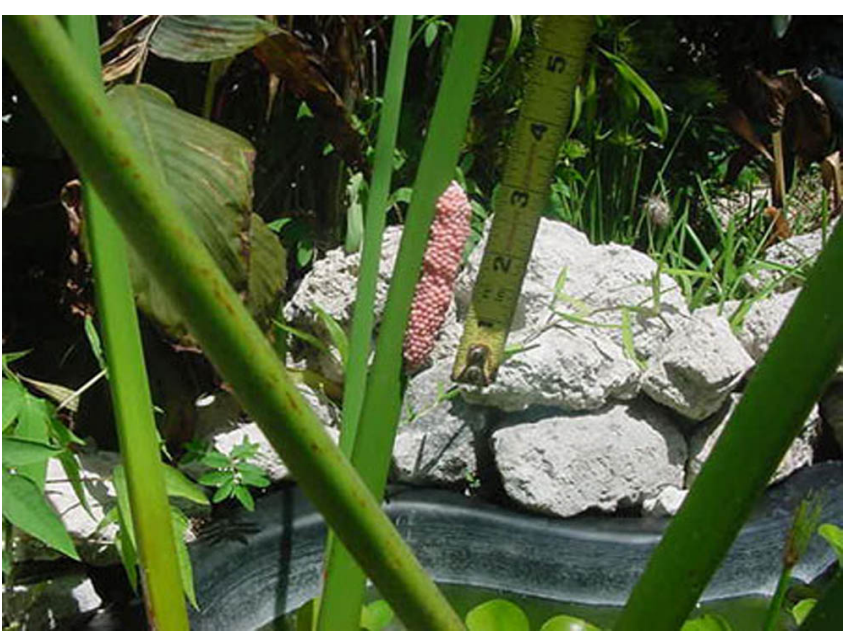

Figure 1. Egg cluster of an applesnail, Pomacea sp. Credits: Photograph by: Barbara Claiborne

The spiketopped applesnail, Pomacea bridgesi, was introduced many years ago into South Florida. However, it is the third species of Pomacea, $P$. canaliculata, that has caused recent concern to agriculture. This species grows nearly twice the size as the other two species and has become a serious rice pest in many countries.

\footnotetext{
1. This document is EENY-323 (originally published as DPI Entomology Circular 388), one of a series of Featured Creatures from the Entomology and Nematology Department, Florida Cooperative Extension Service, Institute of Food and Agricultural Sciences, University of Florida. Published: March 2004. This document is also available on Featured Creatures Website at http://creatures.ifas.ufl.edu. Please visit the EDIS Website at http://edis.ifas.ufl.edu. Additional information on these organisms, including many color photographs, is available at the Entomology and Nematology Department website at http://entnemdept.ifas.ufl.edu/.

2. Lionel A. Stange, Department of Agriculture and Consumer Services, Division of Plant Industry, Gainesville, FL.
}

The Institute of Food and Agricultural Sciences (IFAS) is an Equal Opportunity Institution authorized to provide research, educational information and other services only to individuals and institutions that function with non-discrimination with respect to race, creed, color, religion, age, disability, sex, sexual orientation, marital status, national origin, political opinions or affiliations. U.S. Department of Agriculture, Cooperative Extension Service, University of Florida, IFAS, Florida A. \& M. University Cooperative Extension Program, and Boards of County Commissioners Cooperating. Larry Arrington, Dean 


\section{Key to the Applesnails of Florida}

1. Apical spire of shell strongly rounded or arched, apical whorls bluntly rounded and not elevated (Fig. 2); adult shells about 40-70 mm high . . ... Florida applesnail, Pomacea paludosa (Say)

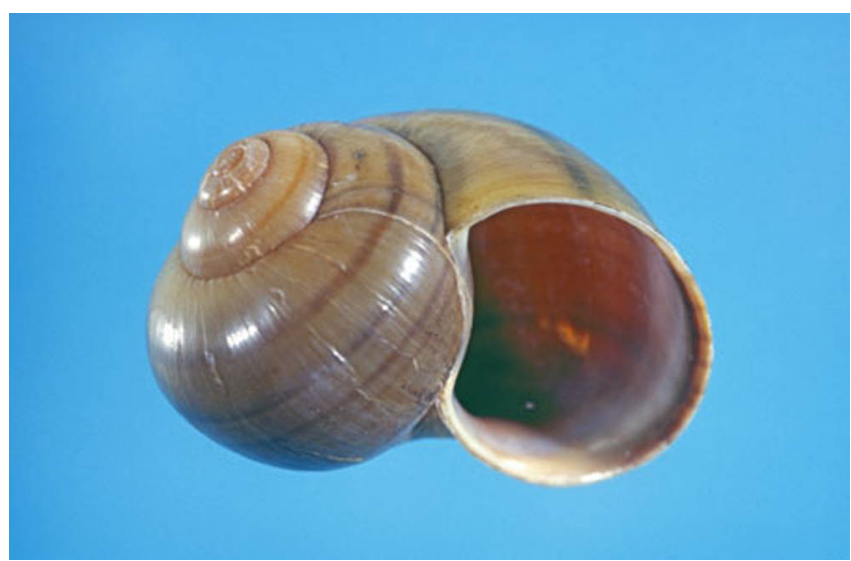

Figure 2. Florida applesnail, Pomacea paludosa (Say). Credits: Photograph by: Jeffrey Lotz, DPI

This is a native snail that has existed in Florida since the Pliocene based on fossil finds. It also occurs in Cuba. It cannot survive low winter temperatures that occur in the northern tier of Florida counties and northward except where the water is artificially heated by industrial wastewater or in warm springs. It occurs as far west as the Choctawhatchee River. Easily distinguished from other applesnails in Florida by the low, rounded shell spike.

1'. Apical spire of shell step-like with nearly flat shoulders and deep sutures, apical whorls forming a point on top of spire (Figs. 3, 5) . . . . 2

2. Shell with each whorl separated from one below by a deep groove or channel (Figs. 3, 4); adult shells 70-95 mm high; varying in color from olive brown to yellowish brown, often with darker bands and blotches ..... channeled applesnail, Pomacea canaliculata (Lamarck)

This large applesnail (shell height up to 100 $\mathrm{mm}$ ) was introduced into South Florida from the Paraguay River System at least as early as 1978. Like the giant African snail, this snail was purposely released into Hawaii, Philippines and Taiwan in the 1980s to be cultured for human consumption.

However, there was little interest in eating these snails and the species spread rapidly from Indonesia to

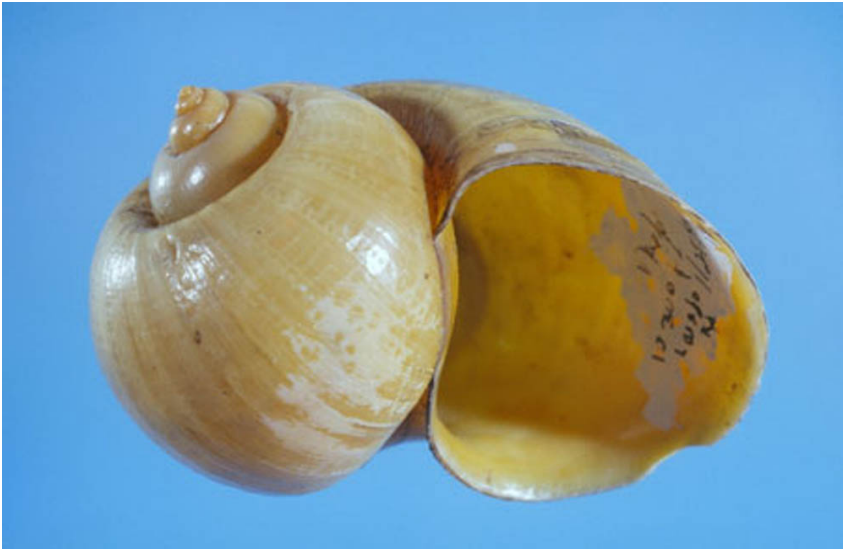

Figure 3. Channeled applesnail, Pomacea canaliculata (Lamarck). Credits: Photograph by: Jeffrey Lotz, DPI

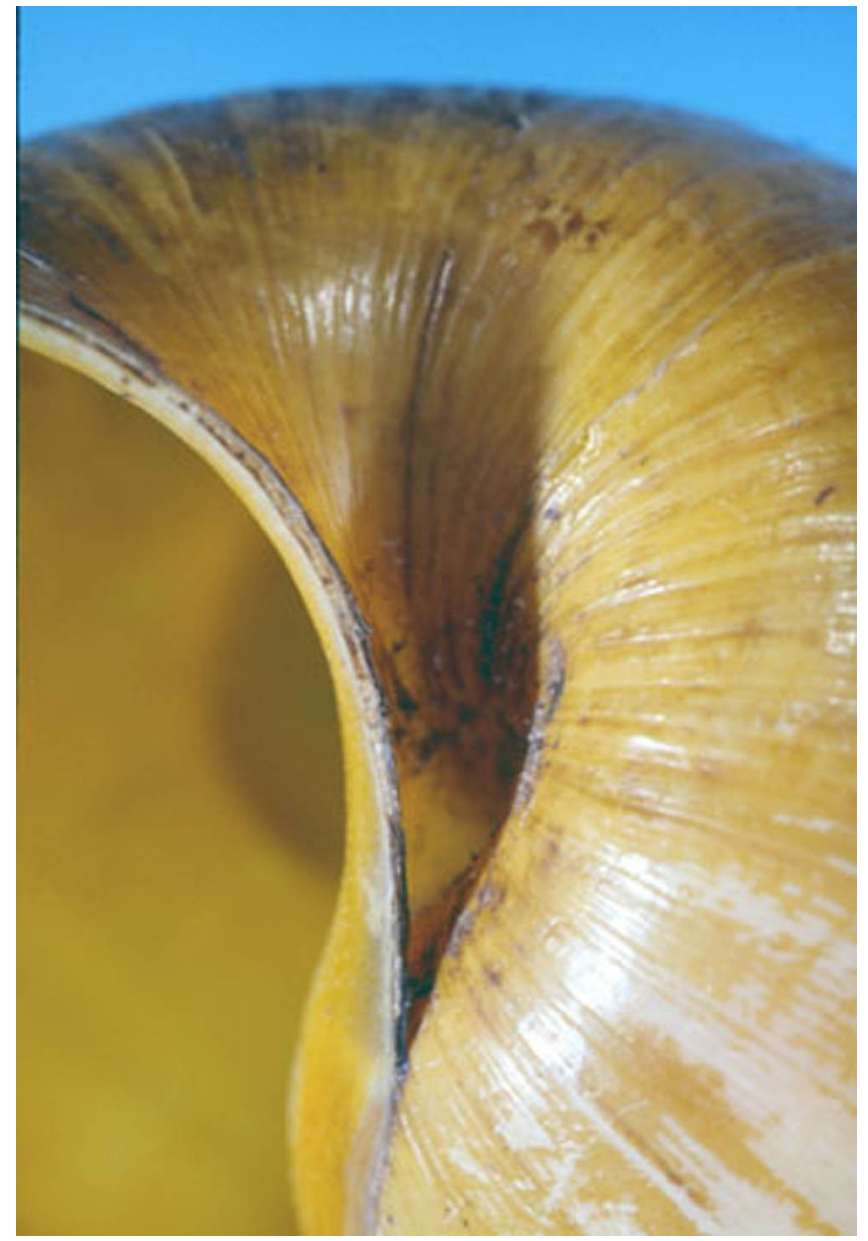

Figure 4. Channeled applesnail, Pomacea canaliculata (Lamarck) showing the deep grove or channel giving it its name. Credits: Photograph by: Jeffrey Lotz, DPI

southern China and Japan. In contrast to the other Florida applesnails, this species feeds aggressively on many types of aquatic and terrestrial plants. In Hawaii, it feeds on taro and rice whereas in southeastern Asia it has been a serious rice pest. It also can host the rat lung worm that can infect 
humans. Apparently this species can survive considerable time out of water and also can hibernate in the mud during cold weather which probably accounts for its presence in Japan. This species can survive up to 50 months (Estebenet and Cazzaniga 1992). In Florida, the species appears to be confined to the coastal zones along the southern half of the peninsula (recorded from Collier, Hillsborough, Palm Beach counties) which have relatively mild winter temperatures. Recently, it has been introduced into Texas and California and has caused alarm because these states grow abundant rice. However, no threat to the small rice industry in Florida is foreseen since 98\% of the rice grown in Florida is summer rice, rotated with sugar cane or vegetables. This is now the largest non-marine snail in Florida. It also can be distinguished by the deep groove or channel between whorls.

2'. Shell without deep groves separating whorls (Fig. 5); adult shells 40-60 mm high; coloration usually greenish with darker and lighter bands in nature ..... spiketopped applesnail, Pomacea bridgesi (Reeve)

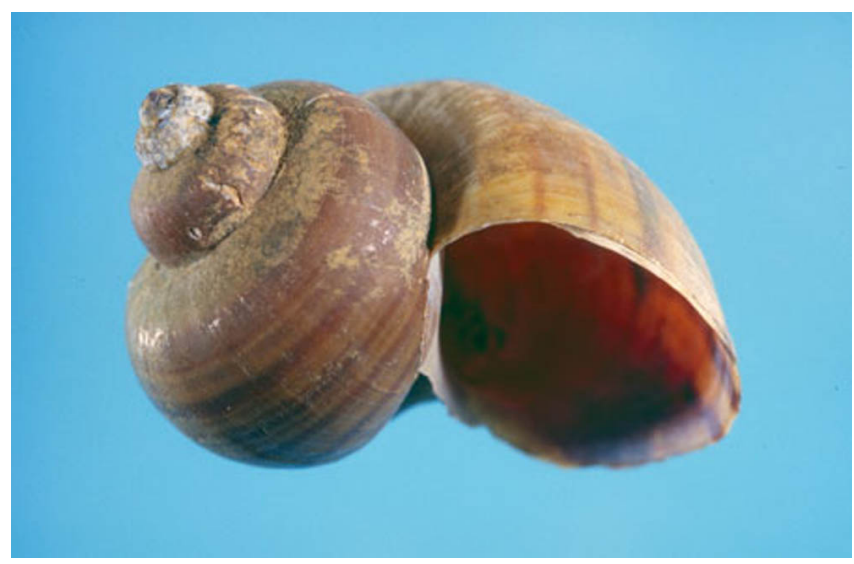

Figure 5. Spiketopped applesnail, Pomacea bridgesi (Reeve). Credits: Photograph by: Jeffrey Lotz, DPI

This is a Brazilian species that was introduced into south Florida probably in the 1950s. This species has a lower tolerance for cold water than the Florida applesnail and is established in Broward, Miami-Dade, Monroe and Palm Beach counties. However, commercial varieties have been bred for the aquarium trade including the "albino mystery snail." These aquarium snails are sometimes dumped into isolated bodies of water and have been recovered as far north as Alachua County (Thompson 1984).

They feed mostly on decaying vegetation.

\section{Selected References}

Estebenet AL, Cazzaniga NJ. 1992. Growth and demography of Pomacea canaliculata

(Gastropoda:Ampullariidae) under laboratory

conditions. Malacological Review 25: 1-12

Ghesquiere S. (2003). Apple snails. http://www.applesnail.net/ (19 March 2004).

Thompson FG. 1984. The Freshwater Snails of Florida. A Manual for Identification. University of Florida Press, Gainesville. 94 p.

Thompson FG. 1997. Pomacea canaliculata (Lamaarck 1822) (Gastropoda, Prosobranchia, Pilidae): A freshwater snail introduced into Florida, U.S.A. Malacological Review 30: 91.

Winner BA. 1991. A Field Guide to Molluscan Spawn, II. Privately published, North Palm Beach. 94 p. 